\title{
Pengaruh obat kumur herbal jeruk nipis (Citrus aurantifolia) terhadap penurunan indeks plak gigi
}

\author{
Meirina Gartika ${ }^{1 *}$, Wartadewi ${ }^{2}$, Hening Tjaturina Pramesti ${ }^{2}$ \\ ${ }^{1}$ Departemen Ilmu Kedokteran Gigi Anak, Fakultas Kedokteran Gigi, Universitas Padjadjaran, \\ Indonesia \\ ${ }^{2}$ Departemen Oral Biologi, Fakultas Kedokteran Gigi,Universitas Padjadjaran, Indonesia \\ *Korespondensi: meirina.gartika@fkg.unpad.ac.id \\ Submisi: 30 September 2019; Penerimaan: 27 Oktober 2019; Publikasi Online: 31 Oktober 2019 \\ DOI: $10.24198 /$ pjdrs.v3i2.24074
}

\begin{abstract}
ABSTRAK
Pendahuluan: Obat kumur herbal jeruk nipis dan klorheksidin dapat membantu menurunkan plak pada permukaan gigi. Penelitian ini bertujuan untuk mengetahui perbedaan efektifitas obat kumur herbal jeruk nipis dan klorheksidin terhadap penurunan nilai indeks plak. Metode: Jenis penelitian berupa eksperimental semu dengan metode intervensi. Teknik pengambilan sampel melalui purposive sampling dan didapat 25 siswa kelas 1 dan 2 di MTs Ma'Arif Jatinangor Sumedang yang memenuhi kriteria. Semua siswa menggunakan kedua obat kumur dengan periode washed out. Pemeriksaan indeks plak sebelum dan sesudah pemakaian obat kumur menggunakan metode Oral Hyigiene Index Simplified (OHIS). Hasil: Sampai penelitian ini selesai, jumlah siswa yang diperiksa indeks plak sebelum dan sesudah penggunaan obat kumur hanya 14 orang karena selama penelitian beberapa siswa tidak dapat hadir. Hasil penelitian menunjukkan bahwa nilai indeks plak sebelum dan sesudah menggunakan obat kumur herbal jeruk nipis terjadi penurunan meski tidak signifikan $(\mathrm{p}=0.307)$ dan tidak ada perbedaan nilai plak skor yang signifikan antara penggunaan obat kumur herbal jeruk nipis dan klorheksidin $(\mathrm{p}=0,135)$. Simpulan: Obat kumur herbal jeruk nipis mempunyai efek dalam menurunkan nilai plak skor.
\end{abstract}

Kata kunci: Obat kumur herbal jeruk nipis, klorheksidin, indeks plak, oral hyigiene index simplified

\section{The effect of herbal mouthwash containing lime (Citrus aurantifolia) in decreasing of index plaque}

\section{ABSTRACT}

Introduction: Herbal mouthwash containing lime and chlorhexidine, both of them can reduce plaque on tooth surface. The aim of study was to determine the differences of the effectiveness between herbal (lime) and chlorhexidine mouthwash on the reduction of plaque index. Methods: This type of research was a quasiexperimental study with an intervention method. The sampling technique was purposive sampling and there have been selected 25 students grade 1 and 2 at MTs Ma'Arif Jatinangor Sumedang who included the criteria. All students used both mouthwashes with a washed out period for three days. Oral Hygiene Index Simplified (OHIS) was used to examine plaque index before and after using mouthwash. Results: By the end of the study, only 14 students attended the whole plaque index determination. The results showed that the plaque index value before and after using herbal lime mouthwash insignificantly decreased ( $p=0.307)$, and there was no notable plaque score difference between herbal lime and chlorhexidine administration $(p=0,135)$. Conclusion: Lime herbal mouthwash has a better effect in reducing plaque than chlorhexidine.

Keywords: lime mouthwash, chlorhexidine, plaque index, oral hyigiene index simplified 


\section{PENDAHULUAN}

Perawatan kesehatan gigi dan mulut yang efektif sangat penting dilakukan oleh setiap individu, termasuk anak-anak. Hal ini dapat dimulai dengan menumbuhkan kebiasaan untuk memelihara kebersihan gigi dan mulut sedini mungkin. Kebiasaaan yang sudah dilakukan sejak kecil diharapkan dapat terus dilakukan hingga dewasa.

Kegagalan dalam menjaga kesehatan gigi dan mulut dapat menimbulkan berbagai gangguan di dalam rongga mulut. Satu gangguan yang sering timbul adalah penumpukan plak. Plak adalah lapisan lunak berupa biofilm yang secara alami melekat pada permukaan gigi dan terbentuk karena ada interaksi secara fisik maupun fisiologis antara bakteri dan permukaan gigi. ${ }^{1}$ Plak dapat ditemukan pada permukaan gigi orang dewasa dan anak-anak.

Plak yang tidak terkontrol dapat menggangu keseimbangan lingkungan di dalam mulut. Plak dapat menyebabkan gingivitis bila dibiarkan, yaitu peradangan pada gusi. Pola makan yang buruk dan perubahan hormonal pada masa pubertas juga dapat menambah risiko gingivitis. ${ }^{2}$ Anak-anak usia remaja sering mengalami gingivitis marginal yang disebabkan adanya akumulasi plak. ${ }^{3}$

Plak dapat hilang melalui tindakan mekanis, seperti menyikat gigi dan penggunaan alat bantu lain seperti benang gigi, tusuk gigi atau obat kumur. Obat kumur dapat membantu mengurangi plak yang tidak dapat dibersihkan dengan menyikat gigi. ${ }^{4}$ Klorheksidin merupakan obat kumur antiseptik golongan biguanida yang merupakan standar emas obat kumur dan digunakan secara luas. Kekurangan klorheksidin adalah dapat menimbulkan pewarnaan pada gigi maupun tambalan, perubahan sensasi rasa, rasa terbakar, sakit dan kering pada jaringan lunak rongga mulut. ${ }^{5}$

Saat ini masyarakat mulai mengenal obat kumur berbahan dasar herbal. Beberapa bahan tersebut telah diketahui dapat menghambat pertumbuhan bakteri melalui gangguan biosintesis protein, metabolisme asam nukleat, dan penghambatan aktivitas enzim seperti glukosiltransferase. ${ }^{6}$ Bahan tersebut juga dapat menghambat bakteri untuk menghasilkan asam, menyintesis eksopolisakarida dan perlekatan bakteri. $^{7}$ Obat kumur yang digunakan dalam penelitian ini mengandung jeruk nipis (Citrus aurantifolia). Ekstrak jeruk nipis mengandung fenol yang dapat menyebabkan denaturasi protein dan menghancurkan membran sitoplasma sel., Tujuan penelitian ini untuk mengetahui perbedaan efektifitas obat kumur herbal jeruk nipis dan klorheksidin terhadap penurunan nilai indeks plak

\section{METODE}

Jenis penelitian adalah eksperimental semu dengan metode intervensi. Penelitian ini disetujui oleh Komisi Etik Penelitian Universitas Padjadjaran dengan No. 42/UN6.KEP/EC/2018. Populasi adalah siswa kelas 1 dan 2 yang bersekolah di MTs Ma'Arif Jatinangor Sumedang. Pemilihan sampel menggunakan purposive sampling dengan kriteria inklusi kesehatan umum baik, bebas karies, kesehatan gusi dan jaringan periodontal baik, tidak mengalami maloklusi dan tidak sedang mengonsumsi antibiotik. Kriteria eksklusinya adalah alergi terhadap bahan obat kumur, memakai protesa atau alat ortodonti dan sedang menggunakan obat kumur terapeutik. Pemeriksaan indeks plak dilakukan sebelum dan sesudah pemberian obat kumur klorheksidin 0,2\% selama 3 hari. Kemudian diberi waktu selama 2 hari untuk periode washed out, selanjutnya pemberian obat kumur herbal jeruk nipis merek Colgate dengan cara yang sama. Pemeriksaan indeks plak menggunakan Oral Hygiene Index Simplified (OHI-S) dari Greene and Vermillion. ${ }^{10}$ Perbedaani nilai plak skor sebelum dan sesudah berkumur dengan obat kumur herbal jeruk nipis atau klorheksidin dianalisis menggunakan uji $t$ berpasangan, sedangkan perbedaan setelah penggunaaan kedua obat kumur tersebut terhadap plak skor dianalisis menggunakan uji t tidak berpasangan.

\section{HASIL}

Diperoleh 25 siswa kelas 1 dan 2 MTs Ma'Arif Jatinangor yang memenuhi kriteria untuk dapat dijadikan subjek penelitian penghitungan plak skor sebelum dan sesudah pemberian obat kumur herbal jeruk nipis dan klorheksidin. Saat penelitian dari 25 siswa tersebut hanya 14 orang siswa yang mengikuti keseluruhan pemeriksaan indeks plak, karena beberapa siswa tidak dapat hadir. Hasil plak skor sebelum dan sesudah pemberian obat kumur klorheksidin disajikan pada Tabel 1, sedangkan nilai plak skor setelah pemberian obat kumur herbal jeruk nipis tampak pada Tabel 2. Perbedaan 
perubahan nilai plak skor antara penggunaan obat kumur herbal jeruk nipis dan klorheksidin

Tabel 1. Nilai plak skor sebelum dan sesudah penggunaan
obat kumur klorheksidin

Keterangan : N: jumlah naracoba, SD: standar deviasi, p<0.05 signifikan dianalisis dengan uji t tidak berpasangan seperti tampak pada Tabel 3.

Tabel 2. Nilai plak skor sebelum dan sesudah penggunaan obat kumur herbal jeruk nipis

\begin{tabular}{cccccc}
\hline $\begin{array}{c}\text { Jeruk } \\
\text { Nipis }\end{array}$ & N & $\begin{array}{c}\text { Rata - Rata } \\
\text { Plak Skor }\end{array}$ & SD & $\begin{array}{c}\text { Nilai } \\
\mathbf{t}\end{array}$ & $\begin{array}{c}\text { Nilai } \\
\mathbf{p}\end{array}$ \\
\hline Sebelum & 14 & 1,27 & 0,35 & & \\
Sesudah & 14 & 1,09 & 0,50 & 1,064 & 0,307
\end{tabular}

Keterangan : N: jumlah naracoba, SD: standar deviasi, $\mathbf{p}<0.05$ signifikan

Tabel 3. Perbandingan nilai plak skor setelah penggunaan obat kumur herbal jeruk nipis dan klorheksidin

\begin{tabular}{|c|c|c|c|c|c|c|c|}
\hline Obat kumur & $\mathbf{N}$ & & $\begin{array}{c}\text { Rata - Rata } \\
\text { Plak Skor }\end{array}$ & Selisih & SD & $\begin{array}{c}\text { Nilai } \\
\mathrm{t}\end{array}$ & $\begin{array}{c}\text { Nilai } \\
\mathbf{p}\end{array}$ \\
\hline & & Sebelum & 1,14 & & & & \\
\hline Klorheksidin & 14 & Sesudah & 1,28 & $-0,14$ & 0,43 & & \\
\hline Jeruk Nipis & 14 & $\begin{array}{l}\text { Sebelum } \\
\text { Sesudah }\end{array}$ & $\begin{array}{l}1,27 \\
1,09\end{array}$ & 0,18 & 0,63 & 1,542 & 0,135 \\
\hline
\end{tabular}

\section{PEMBAHASAN}

Hasil penelitian menunjukkan bahwa indeks plak setelah penggunaan klorheksidin mengalami peningkatan, meskipun tidak signifikan $(\mathrm{p}=0,261)$. Klorheksidin dapat berkurang efektifitasnya jika digunakan beberapa saat setelah menggunakan pasta gigi yang mengandung fluor. Interaksi antara klorheksidin dan fluor dapat membentuk garam sodium monofluorofosfat dan sodium lauril sulfat yang menyebabkan efektivitas klorheksidin berkurang. ${ }^{11}$ Berbeda dengan khlorheksidin, obat kumur yang mengandung fenol dapat langsung digunakan setelah menyikat gigi, karena mekanisme kerja fenol tidak dipengaruhi oleh fluor. Peningkatan nilai indeks plak diduga juga karena penyikatan gigi siswa tersebut masih belum benar.

Mekanisme bakterisidal khlorheksidin terjadi ketika berikatan dengan membran sel bakteri dan ikatan ini akan menyebabkan perubahan permeabilitas dan ketidakseimbangan osmosis sel bakteri. Klorheksidin kemudian akan diserap masuk ke dalam sel. Sitoplasma akan keluar dari sel dan komponen interseluler akan mengendap sampai akhirnya sel bakteri akan mati. ${ }^{12}$

Hasil penelitian ini menunjukkan bahwa indeks plak setelah penggunaan obat kumur herbal jeruk nipis terjadi penurunan dari 1,27 menjadi 1,09, tetapi tidak signifikan $(p=0,307)$. Obat kumur herbal yang digunakan dalam penelitian ini mengandung essential lime oil yang terdiri dari 75\% terpen, 12\% senyawa teroksigenasi dan $3 \%$ sesquiterpene. ${ }^{13}$ Hasil penelitian Fajriani ${ }^{14}$ menunjukkan terjadi penurunan jumlah koloni Streptococcus mutans yang signifikan pada anak-anak yang mengalami early clinical caries setelah berkumur ekstrak jeruk nipis $40 \%$ selama 30 menit. Jeruk nipis (Citrus aurantifolia) merupakan salah satu herbal yang banyak digunakan untuk medikasi karena bersifat antipiretik dan antibakteri. Komposisinya terdiri dari asam sitrat, asam amino (triptofan dan lisin), minyak atsiri, vitamin A, B1, dan C. Ekstrak jeruk nipis mengandung fenol yang dapat menghambat Staphylococcus aureus. Fenol dapat menyebabkan denaturasi protein dan menghancurkan membran sitoplasma sel. Ketidakstabilan dinding sel menyebabkan gangguan pada permeabilitas selektif, fungsi transport aktif dan kontrol protein sel bakteri sehingga mengalami lisis $^{8,9}$

Hasil penelitian menunjukkan bahwa tidak ada perbedaan nilai plak skor yang signifikan setelah penggunaan obat kumur herbal jeruk nipis maupun klorheksidin $(\mathrm{p}=0,135)$. Kedua obat kumur tersebut dapat mengurangi pembentukan pelikel. Mekanisme kerja klorheksidin dapat menghambat aktivitas enzim glukosiltransferase bakteri, sementara obat kumur herbal jeruk nipis dapat mengurangi kemampuan hidrofobisitas membran sel bakteri dengan komponen saliva yang terdapat dalam plak. Bakteri akan sulit menempel pada pelikel/plak. 
Hal ini sesuai dengan penelitian Razak dan Rahim tahun 2003 yang meneliti efektifitas piper betle pada perlekatan plak terhadap gelas yang dilapisi saliva. ${ }^{15}$

\section{SIMPULAN}

Obat kumur herbal jeruk nipis mempunyai efek dalam menurunkan nilai plak skor.

\section{DAFTAR PUSTAKA}

1. Newman MG, Takei HH, Carranza FA. Carranza's Clinical Periodontology. 9th ed. California. WB Sanders Company. 2002;97.

2. Mc Donald RB, Avery DR, Dean JA. Dentistry for the child and adolescent. 8th ed. St Louis. Mosby. 2004; 247-8,253-4,415,478.

3. Pinkham JR. Pediatric dentistry : infancy through adolescence. 4th ed. St Louis. Elsevier Saunders. 2005;693.

4. Malhotra R. Comparison of the effectiveness of a commercially available herbal mouthrinse with chlorhexidine gluconate at the clinical and patient level. J Indian Soc Periodontol. 2011 Oct;15(4):349-52.

5. Gold J. The role of chlorhexidine in caries prevention. Operative Dentisry. 2008;33(6):7101.

6. Kalensinskas PTK, Ambrozaitis A, Peciuliene V, Ericson D. Reducing dental plaque formation and caries development, a review of current methods and implications for novel pharmaceutical. Stomatologija, Baltic Dent and Maxillofacial J. 2014;16(2):44-52.
7. Jeon J, Rosalen P, Falsetta M, Koo H. Natural products in caries research: current (limited) knowledge, challenges and future perspective. Caries Res. 2011;45:243-63.

8. Rao A. Principles and Practice of Pedodontics. 3rd ed. Panama City. Jaypee Brothers Medical 2012:459.

9. Haq W. Efficacy of antiplaque mouthrinse : a five-day clinical trial. General Dentistry 2011;59(3):110-5.

10. Sharma U. A clinical assesment of the effectiveness of mouthwashes comparison to toothbrushing in children. J Indian Soc Pedo Prev Dent June 2004;22(2):38-44.

11. Gamarra FMC, Sakanaka LS, Tambourgi EB, Cabral FA. Influence on the quality of essential nipis (Citrus aurantifolia) oil by distillation process. Brazilian J of Chemical Engineering 2006;23(1):147-51.

12. Fajriani, Mahrum. Effectiveness of lime (Citrus aurantifolia) extract solution in inhibiting bacteria Streptococcus mutans case of early caries childhood. Donnish J of Dentistry and Oral Hygiene 2015;1(4):16-20.

13. Pelczar MJ, ECS Chan, NR Krieg. Microbiology. New York. McGraw-Hill Inc. 1986;491-3.

14. Cowan MM. Plant products as antimicrobial agents. Cliical Microbiology Review. 2009;12(4):465.

15. Razak FA, ZHA Rahim. The anti-adherence effect of piper betle and psidium guajava extracts on the adhesion of early settlers in dental plaque to saliva-coated glass surfaces. J of Oral Sciences. 2003;45(4). 